Teknomekanik

Vol.4, No.2, Dec 2021, pp. 72 77

e-ISSN: 2621-8720 p-ISSN: 2621-9980

\title{
Analysis of Tensile Strength of Citronella (Cymbopogon Nardus) Fiber Reinforced Composite Materials
}

\author{
Julio Lukmanul Ardi, Hendri Nurdin, Andril Arafat and Sri Rizki Putri Primandani
}

Department of Mechanical Engineering, Faculty of Engineering, Universitas Negeri Padang, Padang 25131, Indonesia

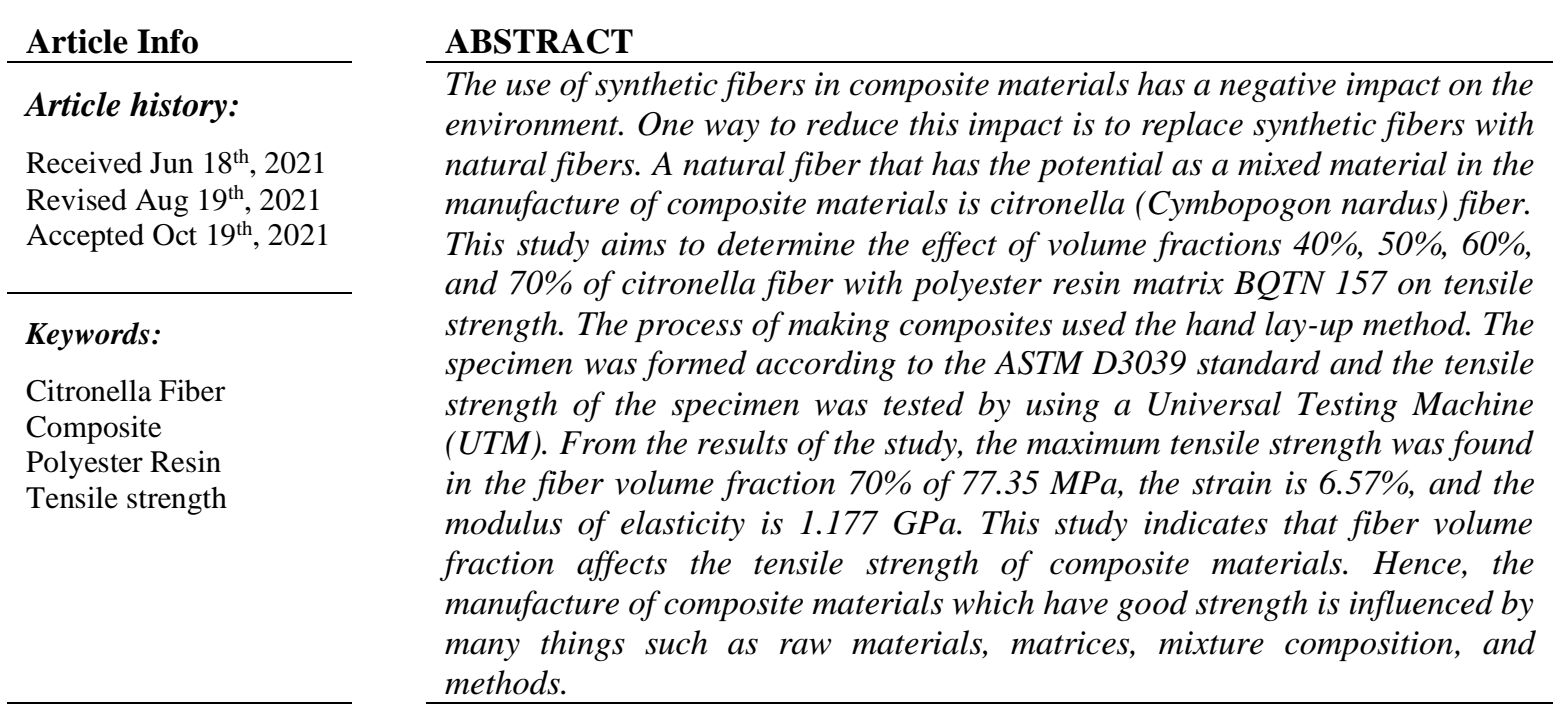

Corresponding Author:

Julio Lukmanul Ardi,

Department of Mechanical Engineering, Faculty of Engineering, Universitas Negeri Padang

Jln. Prof. Dr. Hamka Air Tawar, Padang 25131, Indonesia

Email : juliolukman53@gmail.com

\section{INTRODUCTION}

The development of materials technology, including composites, is still in demand by the general population. It is due to the advantages of composite materials which are easily constructed, lightweight, lowpriced, and environmentally friendly [1]. The most common reinforcement fiber used by the community in composites processing is carbon, glass, and ceramics. However, the use of synthetic fibers will certainly cause damage to the environment because it is difficult to decompose naturally, therefore natural fibers appear as a substitute for synthetic fibers [2]. The mechanical properties of composite materials are influenced by several factors, including the manufacturing process and the constituent materials [3]. According to [4] one that affects the material strength is the matrix. The weakness of synthetic fiber composites is relatively overpriced and it has a tendency to damage the environment [5]. Scientists have found a replacement fiber that is environmentally friendly, non-toxic, relatively inexpensive, and its strong ability can match synthetic fibers [6].

One of the replacements for synthetic fiber is a natural fiber which has the potential to be developed into composite materials. Applications of natural fiber-reinforced composite materials have been widely used such as in connecting rods in vehicles, aerospace, shipping, and sports equipment [7]. The advantages of using natural fibers are accessible raw materials, non-toxic content, ease to recycle, and low environmental impact [8]. The tensile strength of various fibers can be seen in Table 1. 
Table 1 : Tensile strength of some fibers [9]

\begin{tabular}{cccc}
\hline Material & Tensile strength $(\mathbf{M P a})$ & Young's modulus $(\mathbf{G P a})$ & Elongation $(\%)$ \\
\hline e-glass & $1200-1800$ & 72 & $\sim 2.5$ \\
Carbon & $\sim 4000$ & 235 & $\sim 2$ \\
Hemp & $350-800$ & $30-60$ & $1.6-4.0$ \\
Kenaf & $400-700$ & $25-50$ & $1.7-2.1$ \\
Jute & $300-700$ & $20-50$ & $1.2-3.0$ \\
\hline
\end{tabular}

One type of natural fiber that has the potential to be used as a composite raw material is citronella (Cymbopogon nardus), which is one of the plants that are easy to cultivate. It has various benefits and has been used for aromatherapy, food preservatives, and perfumes [10]. The citronella plant is processed to extract the oil, and the waste from the distillation is usually used as fuel during the refining process. It is also used as animal feed and raw material for organic fertilizers. Citronella plants contain essential oils produced from distillation, in which distillation waste has the potential to be used as animal feed because it contains about $7 \%$ protein and high fiber [11]. The composition of chemical compounds in citronella stems can be seen in Table 2 .

Table 2 : Chemical compounds in the stems of citronella (cymbopogon nardus) [12]

\begin{tabular}{cc}
\hline Chemical Compound & Amount $(\boldsymbol{\%})$ \\
\hline cellulose & 39.5 \\
hemicellulose & 22.6 \\
lignin & 28.5 \\
\hline
\end{tabular}

The processing of citronella waste cannot be optimized because this waste is directly disposed of or burned. The use of this waste is certainly beneficial from an economic point of view in the manufacture of composite materials. Therefore, the high fiber content in citronella plants can be used as a mixture to form composite materials [13]. This study aims to utilize citronella waste for the manufacture of composite materials.

\section{METHODS}

This research was an experimental study in which the test results were obtained directly from the specimen. Tools and materials used in the manufacture of composites include,

Materials:

\section{- Citronella Fiber}

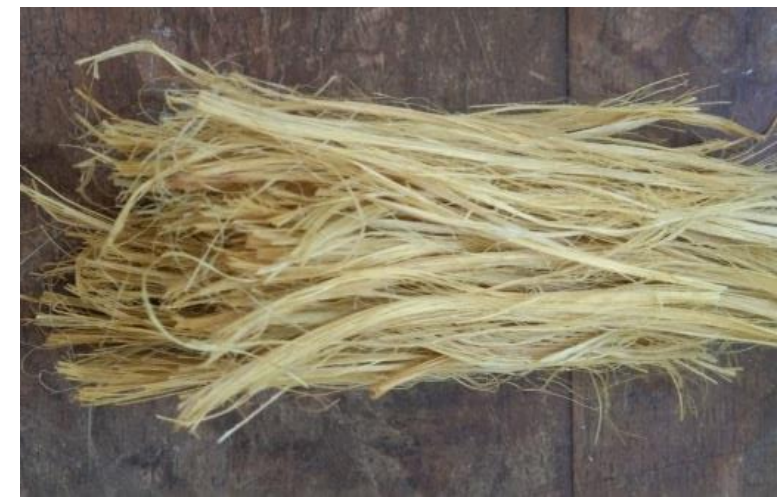

Figure 1 : Citronella Fiber.

- $\quad$ Polyester Resin Yukalac 157 BQTN and Catalyst

Tools:

- $\quad$ Universal Testing Machine (UTM)

Journal homepage: http://teknomekanik.ppj.unp.ac.id

DOI: https://doi.org/10.24036/teknomekanik.v4i2.10472 


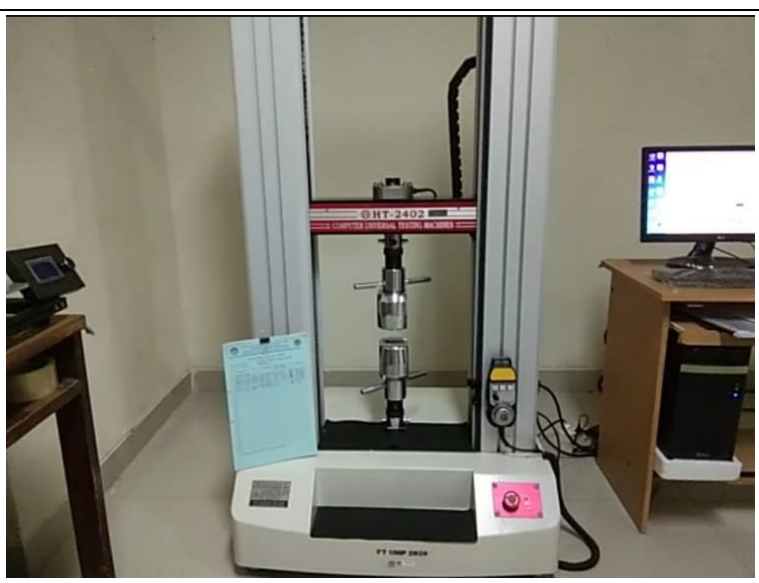

Figure 2 : Universal Testing Machine

- $\quad$ Digital scales

- $\quad$ Measuring cup

- Sample Mold

- $\quad$ Ruler

The manufacture of composite materials used the hand lay-up method. This study focused on the effect of fiber volume fractions $40 \%, 50 \%, 60 \%$, and $70 \%$ with resin matrix BQTN 157 Yukalac on the tensile strength of composite materials. This test used the ASTM D3039 standard based on Table 2.

Table 3 : Tensile Specimen Geometry Reqiurements [14]

\begin{tabular}{ll}
\hline \multicolumn{1}{c}{ Parameter } & \multicolumn{1}{c}{ Requirement } \\
\hline Compound Requirements: & Constant rectangular cross-section \\
Shape & Gripping + 2 time width + gage length \\
Minimum length & As needed \\
Specimen Width & $\pm 1 \%$ of width \\
Specimen width tolerance & As needed \\
Specimen thickness & $\pm 4 \%$ of thickness \\
Specimen thickness tolerance & Flat with light finger pressure \\
Specimen flatness & \\
Tab requirement & As needed \\
Tab material & As needed \\
Fiber orientation & As needed \\
Tab thickness & $\pm 1 \%$ tab thickness \\
Tab thickness variation between & 5 to $90^{\circ}$, inclusive \\
Tab bevel angle &
\end{tabular}
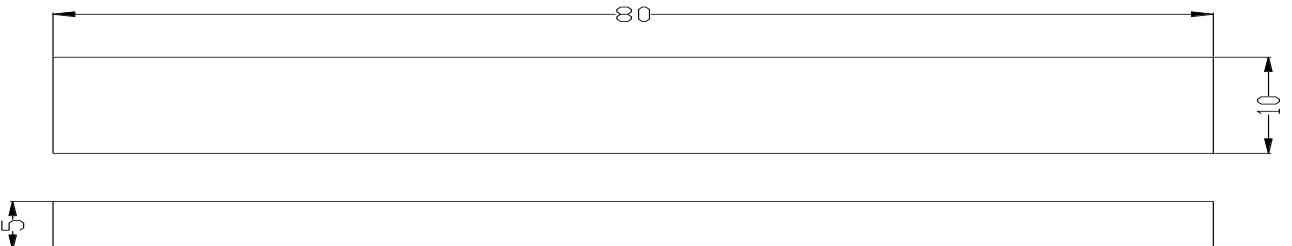

Figure 3 : Dimensions \& Geometry of ASTM D3039 specimen without tabs

The dimensions of the specimen were $80 \mathrm{~mm} \times 10 \mathrm{~mm}$ x $5 \mathrm{~mm}$ without tabs with a test area length of $60 \mathrm{~mm}$ and a grips area of $10 \mathrm{~mm}$ on each side of the specimen. Tensile testing aims to determine the mechanical properties of a material such as stiffness, ductility, and strength[15]. This test was carried out by applying a tensile load to the specimen until it was broken, and the resulting data was in the form of stress-strain curve, elongation, and modulus of elasticity. Stress is a force per unit area, and it was obtained by equation 1 .

Journal homepage: http://teknomekanik.ppj.unp.ac.id

DOI: https://doi.org/10.24036/teknomekanik.v4i2.10472 


$$
\sigma=\frac{F}{A}
$$

Strain is the increase in the length of the object per initial length. Strain was obtained by equation 2.

$$
\varepsilon=\frac{\Delta l}{l o}
$$

According to [16] Volume fraction is defined as a combination of fiber volume and matrix volume used to determine the composite volume, through equation 3 .

$$
v_{c}=v_{f}+v_{m}=\frac{m_{f}}{\rho_{f}}+\frac{m_{m}}{\rho_{m}}
$$

As a control material, the fiber volume fraction can be obtained by equations 4 and 5 .

$$
\begin{aligned}
& V_{f}=\frac{v_{f}}{v_{c}} \times 100 \% \\
& W_{f}=\frac{m_{f}}{v_{c}} \times 100 \%
\end{aligned}
$$

\subsection{Composite Manufacturing Process}

The raw material was obtained from the citronella distillation waste in South Limau Manis, Padang. Citronella stem waste was soaked for 3-4 days. This process was intended to let the substances attached to the fibers soften so it facilitated the separation of the fibers in the stems. The process of separating the fibers in the citronella stems was done by shaving the citronella stems repeatedly until clean fibers were obtained and then dried without sunlight. The dried fibers were soaked in an alkaline solution $(5 \% \mathrm{NaOH})$ for 30 minutes, then the fibers were cleaned with running water and dried without sunlight. The matrix used was polyester resin yukalac BQTN 157. Composites were made by hand lay-up method. The ratio of resin and hardener was 10:1 and the fiber volume fraction (Vf) was $40 \%, 50 \%, 60 \%, 70 \%$. The tensile test sample was printed using glass and it was pressed. Then the sample was cut to form a specimen according to the ASTM D-3039 standard. The specimen pieces were smoothed using sandpaper. The tensile testing used UTM (Universal Testing Machine) with a capacity of $50 \mathrm{kN}$. The results are shown in the form of the relationship between tensile properties and fiber volume fraction (Vf).

\begin{tabular}{|c|c|c|c|c|}
\hline \multicolumn{2}{|c|}{ Volume Fraction } & \multirow{2}{*}{$\begin{array}{l}\text { Tensile } \\
\text { Strength } \\
\text { (MPa) }\end{array}$} & \multirow{2}{*}{ Strain (\%) } & \multirow{2}{*}{$\begin{array}{c}\text { Modulus of } \\
\text { Elasticity } \\
\text { (GPa) }\end{array}$} \\
\hline Fiber & Resin & & & \\
\hline $40 \%$ & $60 \%$ & 46.5 & 8.00 & 0.581 \\
\hline $50 \%$ & $50 \%$ & 51.59 & 8.3 & 0.644 \\
\hline $60 \%$ & $40 \%$ & 55.71 & 7.33 & 0.775 \\
\hline $70 \%$ & $30 \%$ & 77.35 & 6.57 & 1.177 \\
\hline
\end{tabular}

\section{RESULTS AND DISCUSSION}

Specimen testing was carried out by using universal Testing Machine (UTM). The average tensile test results can be seen in Table 4.

Table 4 : The results of average tensile test of the composite

It can be seen in table 3 the results of the average tensile test on fiber volume fractions of $40 \%, 50 \%, 60 \%$ , and $70 \%$ of the resin yukalac BQTN 157. So that the graph of the relationship between stress and volume fraction is obtained in Figure 4. 


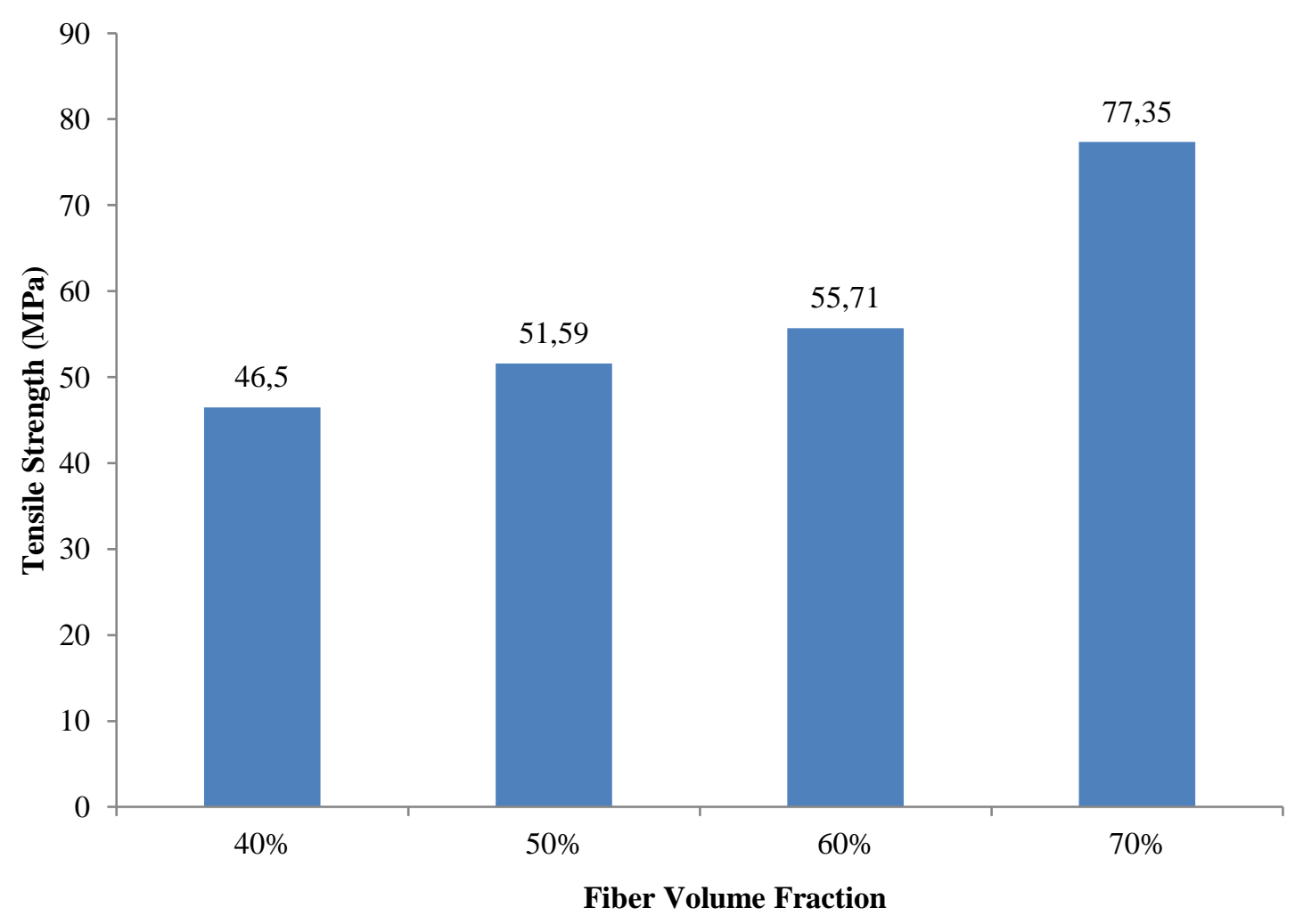

Figure 4 : Graph of the relationship between tensile strength and fiber volume fraction

The graph shows the tensile strength in the fiber volume fraction $40 \%$ with a value of $46.5 \mathrm{MPa}$. In the volume fraction of $50 \%$ it has a tensile strength of $51.59 \mathrm{MPa}$. The fiber volume fraction $60 \%$ has a tensile strength of $55.71 \mathrm{MPa}$ and the tensile strength value in the volume fraction $70 \%$ is $77.35 \mathrm{MPa}$. The above research proves that there is an effect of volume fraction on the tensile strength of composite materials. The results of this study are in line with the opinion of [17]. According to him, the tensile strength of the composite material increases with the increase in the volume fraction of the fiber.

\section{CONCLUSION}

Based on the above research, it can be concluded that the variation of the fiber volume fraction has an effect on the tensile strength of the composite material, where the volume fraction of $70 \%$ fiber produces a maximum tensile strength of $77.35 \mathrm{MPa}$ while the volume fraction of $40 \%$ fiber produces a minimum tensile strength of $46.5 \mathrm{MPa}$. The test results indicate that the tensile strength of the composite increases with increase in fiber volume. The manufacture of composite materials which have good strength is influenced by many things such as raw materials, matrices, mixture composition, and methods.

\section{REFERENCES}

[1] Z. Zulkifli, H. Hermansyah, and S. Mulyanto, "Analisa Kekuatan Tarik dan Bentuk Patahan Komposit Serat Sabuk Kelapa Bermatriks Epoxyterhadap Variasi Fraksi Volume Serat,” JTT (Jurnal Teknol. Terpadu), vol. 6, no. 2, p. 90, 2018, doi: 10.32487/jtt.v6i2.459.

[2] D. B. Miracle and S. L. Donaldson, Composites, Volume 21. ASM Intenational, 2001.

[3] N. H. Sari, I. Yudhyadi, and S. Emmy, "Karakteristik Kekuatan Bending Kayu Komposit Polyester Diperkuat Serat Pandan Wangi dengan Filler Serbuk Gergaji Kayu," J. Energi Dan Manufaktur, vol. 6, no. 2, pp. 157-164, 2014.

[4] H.- Nurdin, Y. Fernanda, and M. Handayani, "Analysis of Tensile Strength the Fiber Bagasse Particles Board with Resin Adhesives," Teknomekanik, vol. 1, no. 1, pp. 1-5, 2018, doi: 10.24036/tm.v1i1.172.

[5] H. A. Wuriyudani, S. Sulhadi, and T. Darsono, "Pemanfaatan Serat Pelepah Pisang Sebagai Bahan Tali Tahan Air," vol. VI, pp. SNF2017-MPS-93-SNF2017-MPS-98, 2017, doi: 10.21009/03.snf2017.02.mps.15.

[6] H. Yudo and S. Jatmiko, “Analisa Teknis Kekuatan Mekanis Material Komposit,” Kapal, vol. 5, no. 2, 
pp. 95-101, 2008.

[7] R. H. Martin, S. Giannis, S. Mirza, and K. Hansen, "Biocomposites in challenging automotive applications," ICCM Int. Conf. Compos. Mater., 2009.

[8] A. D. Afenanda, teguh D. Widodo, and R. Raharjo, "Pengaruh Perlakuan Larutan NaOH terhadap Kekuatan Tarik Komposit Serat Batang Serai Wangi (Cymbopogon nardus) Bermatriks Epoxy,” pp. 111,2018

[9] A. T. Submitted, I. N. Partial, F. Of, R. For, T. H. E. Degree, and P. Tudu, "Processing and Characterization of Natural Fiber Reinforced Polymer Composite," Int. J. Eng. Adv. Technol., vol. 9, no. 2, pp. 755-757, 2019, doi: 10.35940/ijeat.b2663.129219.

[10] N. S. Kamarudin, R. Jusoh, H. D. Setiabudi, N. W. C. Jusoh, N. F. Jaafar, and N. F. Sukor, "Cymbopogon nardus mediated synthesis of ag nanoparticles for the photocatalytic degradation of 2,4dicholorophenoxyacetic acid," Bull. Chem. React. Eng. \&amp;amp; Catal., vol. 14, no. 1, pp. 173-181, 2019, doi: 10.9767/bcrec.14.1.3321.173-181.

[11] M. Djazuli, D. Suheryadi, B. Penelitian, T. Obat, J. Tentara, and P. No, "Seraiwangi ( Cymbopogon nardus L ) Sebagai Penghasil Minyak Atsiri , Tanaman Konservasi Dan Pakan Ternak," Inov. Perkeb. 2011, pp. 174-180, 2011, [Online]. Available: http://perkebunan.litbang.deptan.go.id/wpcontent/uploads/2012/04/perkebunan_prosdENIP11_MP_Sukamto2.pdf.

[12] L. D. Bekele et al., "Preparation and characterization of lemongrass fiber (Cymbopogon species) for reinforcing application in thermoplastic composites," 2017.

[13] A. N. M. A. Haque, R. Remadevi, and M. Naebe, "Lemongrass (Cymbopogon): a review on its structure, properties, applications and recent developments," Cellulose, vol. 25, no. 10, pp. 5455-5477, 2018, doi: 10.1007/s10570-018-1965-2.

[14] ASTM D3039, "Standard Test Method for Tensile Properties of Polymer Matrix Composite Materials1," in ASTM International, West Conshohocken, 2002.

[15] J. Martin, Materials for engineering, Third edit., vol. 21, no. 5. England: Woodhead Publishing Ltd, 2013.

[16] M. B. N. Rahman and B. P. Kamel, "Pengaruh Fraksi Volume Serat terhadap Sifat-sifat Tarik Komposit Diperkuat Unidirectional Serat Tebu dengan Matrik Poliester,” Jurnla Ilm. Semesta Tek., vol. 14, no. 2 , pp. 133-138, 2011.

[17] P. D. Setyawan, N. H. Sari, and D. G. Pertama Putra, "Pengaruhorientasi Danfraksi Volume Serat Daun Nanas (Ananas Comosus)Terhadap Kekuatan Tarik Komposit Polyestertak Jenuh(Up)," Din. Tek. Mesin, vol. 2, no. 1, pp. 28-32, 2012, doi: 10.29303/d.v2i1.108.

\section{NOMENCLATURE}

$\sigma \quad$ Tensile Stress (MPa)

$F \quad$ Force $(\mathrm{N})$

A $\quad$ Area $\left(\mathrm{mm}^{2}\right)$

$\varepsilon \quad$ Strain $(\%)$

$\Delta l \quad$ Length Increase $(\mathrm{mm})$

lo Initial Length $(\mathrm{mm})$

$v_{c} \quad$ Composite volume $\left(\mathrm{cm}^{3}\right)$

$v_{f} \quad$ Fiber volume $\left(\mathrm{cm}^{3}\right)$

$v_{m} \quad$ Matrix volume $\left(\mathrm{cm}^{3}\right)$

$m_{f} \quad$ Fiber mass (gr)

$\rho_{f} \quad$ Fiber density $\left(\mathrm{gr} / \mathrm{cm}^{3}\right)$

$m_{m} \quad$ Matrix mass (gr)

$\rho_{m} \quad$ Matrix density $\left(\mathrm{gr} / \mathrm{cm}^{3}\right)$

$V_{f} \quad$ Fiber volume fraction (\%)

$W_{f} \quad$ Fiber weight fraction $(\%)$

Journal homepage: http://teknomekanik.ppj.unp.ac.id

DOI: https://doi.org/10.24036/teknomekanik.v4i2.10472 